\title{
К ВОПРОСУ О СОДЕРЖАНИИ АМИНОКИСЛОТ И ВОДОРАСТВОРИМЫХ ВИТАМИНОВ У НЕКОТОРЫХ ПРЕДСТАВИТЕЛЕЙ СЕМЕЙСТВА HYDROCHARITACEAE
}

\author{
() А.Н. Ерремов ${ }^{1 *}$, Е.А. Алехина ${ }^{1}$, Д.Е. Иминова ${ }^{2}$, Н.К. Омаргалиева ${ }^{2}$ \\ ${ }^{1}$ Омский государственный педагогический университет, наб. Тухачевского, \\ 14, Омск, 644099 (Россия), e-mail: stratiotes@yandex.ru \\ ${ }^{2}$ Научный центр радиоэкологических исследований государственного \\ университета им. Шакарима, ул. Физкультурная, 4А, Семей, 071412 \\ (Республика Казахстан)
}

\begin{abstract}
Выполнено исследование содержания аминокислот (валина, аргинина, триптофана, метионина, лизина, гистидина, фенилаланина, изолейцина) и водорастворимых витаминов $\left(\mathrm{B}_{1}, \mathrm{~B}_{2}, \mathrm{~B}_{6}, \mathrm{C}\right)$ у видов семейства Hydrocharitaceae, произрастающих на территории Западной Сибири (Elodea canadensis, Stratiotes aloides, Hydrocharis morsus-ranae, Hydrilla verticillata).

У исследуемых представителей семейства обнаружены пять незаменимых (валин, изолейцин, лизин, триптофан, фенилаланин) и две заменимых (аргинин, гистидин) аминокислоты. У всех исследуемых Hydrocharitaceae наблюдается сравнительно высокое содержание валина (максимальное у H. morsus-ranae $(420 \pm 30) \times 10^{-7}$ г/100 г). Характерным является высокое содержание витамина С (максимальное у S. aloides $-(770 \pm 30) \times 10^{-7}$ и H. morsus-ranae $-(750 \pm$ $30) \times 10^{-7}$ г/100 г) и одинаково низкое у всех исследуемых видов витамина $\mathrm{B}_{6}\left(\right.$ на уровне $(19 \pm 2) \times 10^{-7} \Gamma / 100$ г).

Ключевые слова: Hydrocharitaceae, Stratiotes aloides, Elodea canadensis, Hydrocharis morsus-ranae, Hydrilla verticillata, аминокислоты, водорастворимые витамины, Западная Сибирь.
\end{abstract}

\section{Введение}

Семейство Hydrocharitaceae на территории Западной Сибири представлено пятью видами, один из которых (элодея канадская Elodea canadensis Michx.) является широко распространенным инвазивным [1]. Все представители семейства обладают высокой парциальной активностью, нередко выступают в роли эдификатора в пресноводных фитоценозах. Сообщества с участием E. canadensis, телореза алоэвидного Stratiotes aloides L. и водокраса обыкновенного Hydrocharis morsus-ranae L. отличаются также и высокой продуктивностью. Гидрилла мутовчатая Hydrilla verticillata (L. f.) Royle - редкий в регионе вид [2-5].

Для представителей семейства характерным является наличие флавонов, флавоновых $C$-гликозидов, флавоновых сульфатов, фенольных гликозидов, цианидина, цианиновых и полифенольных гликозидов, хлорогеновой кислоты, высших жирных кислот. Для семейства Hydrocharitaceae показано отсутствие алкалоидов, иридоидов, сапонинов, сапогенинов и эллаговой кислоты [6-8]. Отдельные представители имеют

Ефремов Андрей Николаевич - научный сотрудник, кандидат биологических наук,

e-mail: stratiotes@yandex.ru

Алехина Елена Анатольевна - доцент кафедры химии и методики преподавания химии, кандидат педагогических наук, e-mail: chemconf@mail.ru Иминова Дилраба Етахуновна - консультант, e-mail: d.iminova@mail.ru

Омаргалиева Назым Кабдулмухитовна - специалист высшего уровня, e-mail: nazim_argin@mail.ru свои видоспецифичные особенности. Так, у H. morsus-ranae есть проантоцианидины (цианидин), которые отсутствуют у других представителей семейства [7, 8]. Для S. aloides характерно наличие хромонов, для $H$. verticillata - фенолкарбоновых кислот, а для E. canadensis - дитерпеноидов [9]. Систематика Hydrocharitaceae разработана недостаточно и продолжает оставаться предметом дискуссий [8]. Привлечение биохимических таксонспецифич-

\footnotetext{
* Автор, с которым следует вести переписку.
} 
ных признаков может быть использовано для решения спорных вопросов систематики при установлении родства $[10,11]$.

Аминокислоты и витамины являются важными биологически активными соединениями. Поиск и получение биологически активных соединений из альтернативных природных источников - одна из приоритетных задач [12]. Поэтому сравнительное исследование содержания аминокислот и водорастворимых витаминов у представителей Hydrocharitaceae, обитающих на территории Западной Сибири, представляет практический и научный интерес.

Ранее состав и содержание аминокислот и витаминов у представителей семейства Hydrocharitaceae частично рассматривались исследователями (табл. 1).

Таблица 1. Содержание аминокислот, витаминов и витаминоподобных веществ у некоторых представителей Hydrocharitaceae

\begin{tabular}{|c|c|c|}
\hline Вид & Аминокислоты & $\begin{array}{c}\text { Витамины и витаминоподобные } \\
\text { вещества }\end{array}$ \\
\hline $\begin{array}{l}\text { Elodea } \\
\text { canadensis }\end{array}$ & $\begin{array}{c}\text { Аргинин }-7,35 \%, \text { гистидин }-4,42 \%, \text { лизин }-11,12 \%, \text { цистин - } \\
0,46 \% \text { абсолютно-сухого сырья [13] }\end{array}$ & $\begin{array}{c}\mathrm{C}-2,4 \times 10^{-3}, \text { каротин }-16,7 \times \\
10^{-3} \text { г/100г воздушно-сухого } \\
\text { сырья, В, К, Е [13] }\end{array}$ \\
\hline $\begin{array}{l}\text { Hydrocharis } \\
\text { morsus-ranae }\end{array}$ & - & $\begin{array}{c}\text { Каротин } 1295 \times 10^{-3} \text { г/100 г аб- } \\
\text { солютно-сухого сырья [13] }\end{array}$ \\
\hline $\begin{array}{l}\text { Hydrilla } \\
\text { verticillata }\end{array}$ & Лизин [14], аспарагин, аланин, аргинин [15] & $\mathrm{B}_{12}[14]$ \\
\hline $\begin{array}{l}\text { Stratiotes } \\
\text { aloides }\end{array}$ & $\begin{array}{c}\text { Аспарагиновая кислота }-0,4 \pm 0,1, \text { глугаминовая кислота }-0,46 \\
\pm 0,09, \text { серин }-0,12 \pm 0,03, \text { гистидин- } 0,18 \pm 0,04, \text { глицин }-0,19 \\
\pm 0,04, \text { треонин- }-0,11 \pm 0,02, \text { аргинин }-0,38 \pm 0,09, \text { аланин- } \\
0,32 \pm 0,08, \text { метионин }-0,10 \pm 0,02, \text { тирозин }-0,16 \pm 0,04, \text { валин } \\
-0,56 \pm 0,09, \text { фенилаланин }-0,5 \pm 0,1, \text { изолейцин- }-0,45 \pm 0,09, \\
\text { лейцин }-0,6 \pm 0,1, \text { лизин }-0,20 \pm 0,05, \text { цистин }-0,17 \pm 0,04, \\
\text { триптофан- } 0,10 \pm 0,02 \% \text { воздушно-сухого сырья [16] }\end{array}$ & $\begin{array}{c}\mathrm{B}_{2}-(11 \pm 2) \times 10^{-3}, \mathrm{E}-(5,9 \pm \\
0,9) \times 10^{-3}, \mathrm{~A}-(1,3 \pm 0,2) \times 10^{-3} \\
\text { г/100г воздушно-сухого сырья, } \\
\mathrm{C}-(3,8 \pm 0,8) \times 10^{-3} \text { г } / 100 \text { г сы- } \\
\text { рого сырья }[16]\end{array}$ \\
\hline
\end{tabular}

\section{Экспериментальная часть}

Материал для исследования был собран в 2014 г. в пойменных водоемах бассейна Иртыша в пределах лесостепной подзоны (табл. 2). Для исследования компонентного состава отбор проб растений проводили в фазу цветения - начала плодоношения/вегетации после цветения (в июле - августе).

Отобранные рандомизированным путем средние пробы фитомассы после первичной пробоподготовки хранили в морозильной камере при температуре минус $18-20{ }^{\circ} \mathrm{C}$, перед проведением испытаний пробы высушивали до воздушно-сухого состояния. Исследования выполнены на базе лаборатории органической химии Омского государственного педагогического университета (Россия) и испытательной региональной лаборатории инженерного профиля «Научный центр радиоэкологических исследований» Государственного университета им. Шакарима г. Семей (Казахстан).

Физико-химический анализ содержания витаминов выполнен с использованием ГОСТ 55482-2013 [17], аминокислот - ГОСТ 13496.21-87 [18] и ГОСТ 32195-2013 [19]. Всего исследовано 3 средних пробы каждого вида.

Исследования выполнялись на жидкостном хроматографе LC-20 Prominence (Shimadzu, Япония): с градиентным элюированием при определении аминокислот, с флуориметрическим и спектрофотометрическим детекторами при определении витаминов. Для разделения компонентов использовали хроматографическую колонку 250 × 4,6 мм «Supelco C18,5 мкм» с предколонкой.

Таблица 2. Места сбора объектов исследования

\begin{tabular}{|c|c|c|}
\hline Объект исследования & Местонахождение & Местообитание \\
\hline $\begin{array}{l}\text { Stratiotes aloides (побеги), } \\
\text { Hydrocharis morsus-ranae } \\
\text { (побеги) }\end{array}$ & $\begin{array}{l}55^{\circ} 13^{\prime} 35^{\prime \prime} \text { с. ш., } 73^{\circ} 00^{\prime} 23^{\prime \prime} \text { в. д., Омская об- } \\
\text { ласть, Любинский район, окрестности с. Лю- } \\
\text { бино-Малороссы, долина Иртыша, протока }\end{array}$ & $\begin{array}{c}\text { Глубина 0,0-1,8, грунт черный грубо- } \\
\text { детритный ил, фитоценоз Stratiotes } \\
\text { aloides aquiherbosa }\end{array}$ \\
\hline $\begin{array}{l}\text { Hydrilla verticillata (побеги), } \\
\text { Elodea canadensis (побеги) }\end{array}$ & $\begin{array}{c}55^{\circ} 13^{\prime} 14^{\prime \prime} \text { с. ш., } 72^{\circ} 59^{\prime} 24^{\prime \prime} \text { в. д., Омская об- } \\
\text { ласть, Любинский район, окрестности с. Лю- } \\
\text { бино-Малороссы, долина Иртыша, особо } \\
\text { охраняемая природная территория «Пойма } \\
\text { Любинская», протока }\end{array}$ & $\begin{array}{c}\text { Глубина 0,1-2,5, грунт глинистый с } \\
\text { грубо детритным наилком, фитоцено- } \\
\text { зы Elodea canadensis purum и Elodea } \\
\text { canadensis + Hydrilla verticillata }\end{array}$ \\
\hline
\end{tabular}


В работе применяли стандартные растворы витаминов (Sigma-Aldrich, США), фосфорной кислоты 85\% (Sigma-Aldrich, CШA), ацетонитрил особой чистоты (HLPC, Германия). Пробоподготовка включала измельчение сырья на роторной мельнице до однородного состояния, экстракцию 0,001 М раствором хлористоводородной кислоты при температуре $70-80{ }^{\circ} \mathrm{C}$ с использованием ультразвуковой ванны «Сапфир РМД» (Россия) и центрифугирование на центрифуге ОПн-3.02 «Дастан» (Кыргызстан) при скорости 7000-8000 об./мин. Центрифугат отфильтровывали через мембранный фильтр для очистки от механических примесей. Фильтрат переносили в виалки и анализировали, используя обращенно-фазовый вариант, градиентное элюирование (температура колонки $-20{ }^{\circ} \mathrm{C}$, скорость элюирования потока - 0,8 мл/мин.). Полученные растворы подвергали хроматографическому анализу. Концентрацию витаминов в пробах вычисляли согласно формуле 1

$$
X=\frac{C_{s} \cdot V_{p} \cdot S_{x} \cdot 10^{-3}}{S_{s} \cdot m},
$$

где $\mathrm{C}_{\mathrm{S}}$ - концентрация витамина в рабочем стандартном растворе, мг/мл; $\mathrm{V}_{\mathrm{p}}$ - объем экстракта пробы, мл; $\mathrm{S}_{\mathrm{x}} \mathrm{S}_{\mathrm{s}}$ - площади пиков витаминов на хроматограмме пробы и стандарта; $\mathrm{m}$ - масса навески пробы, г; $\mathrm{X}$ концентрация витаминов в пробах, г/100 г сухого вещества.

Подготовку образцов для определения аминокислот проводили следующим образом. Для гидролиза к 100 мг образца добавляли 10 мл 6 М раствора хлористоводородной кислоты. Смесь тщательно перемешивали и обдували током азота в течение 2 мин. Стеклянные ампулы запаивали и помещали в термостат. Гидролиз проводили при температуре $110{ }^{\circ} \mathrm{C}$ в течение 24 ч. Аликвоты высушивали при $65{ }^{\circ} \mathrm{C}$ в токе воздуха, добавляли 0,15 М раствор гидроксида натрия и раствор фенилизотиоционата в изопропиловом спирте, далее фильтровали через мембранный фильтр с диаметром пор 0,45 мкм. Полученные растворы подвергали хроматографическому анализу.

Определения проводили при расходе элюента 1,2 мл/мин. и температуре колонки термостата $40{ }^{\circ} \mathrm{C}$. Измерения выполняли при длинах волн 246 и 260 нм с использованием кислотного гидролиза и модификации аминокислот раствором фенилизотиоционата в изопропиловом спирте с получением фенилтиогидантоинов. В качестве подвижной фазы использовали смесь 6,0 М раствора ацетата натрия с рН 5,5, 1\% раствор изопропилового спирта в ацетонитриле и 6,0 М раствора ацетата натрия с рН 4,05. Применяли стандартные образцы аминокислот (Sigma Aldrich), ацетонитрила, изопропилового спирта, фенилизотиоционата (Sigma Aldrich), ацетат натрия, хлористоводородную кислоту и гидроксид натрия особой чистоты.

Концентрацию аминокислот вычисляли по формуле 2:

$$
X=\frac{C_{r} \cdot V \cdot S_{r} \cdot 10^{-3}}{S_{c m} \cdot m},
$$

где $\mathrm{C}_{\mathrm{r}}$ - концентрация аминокислоты в рабочем стандартном растворе, мг/мл; $\mathrm{V}$ - конечный объем гидролизата, мл; $\mathrm{S}_{\mathrm{r}}$ - площадь пика аминокислоты в исследуемой пробе; $\mathrm{S}_{\mathrm{cт}}$ - площадь пика аминокислоты стандартного рабочего раствора; $\mathrm{m}$ - масса навески пробы, взятой на гидролиз, мг; $\mathrm{X}$ - концентрация витаминов в пробах, г/100 г сухого вещества.

Статистическая обработка результатов выполнена средствами пакета Statistica 6.1 (описательная статистика, проверка на нормальность распределения) и PAleontological STatistics 3.08 (кластерный анализ методом парного сравнения) [20].

\section{Обсуждение результатов}

Результаты определения содержания аминокислот и витаминов в фитомассе E. canadensis, S. aloides, H. morsus-ranae и H. verticillata приведены в таблицах 3-4 и на рисунке 1.

У всех исследованных представителей семейства Hydrocharitaceae не обнаружен метионин, содержание валина сравнительно высокое. У H. verticillata и S. aloides наблюдается высокое содержание фенилаланина, а у E. canadensis и H. morsus-ranae - изолейцина (табл. 3). При кластерном анализе по содержанию аминокислот на уровне 200-300 выделяются две группы видов: H. verticillata + S. aloides и E. canadensis + H. morsus-ranae (рис. 2A). 
Таблица 3. Содержание аминокислот в фитомассе растений семейства Hydrocharitaceae

\begin{tabular}{l|c|c|c|c}
\hline \multirow{2}{*}{ Аминокислота } & \multicolumn{4}{|c}{ Содержание аминокислот, $10^{-1}$ г/100 г сухого сырья } \\
\cline { 2 - 5 } & $\begin{array}{c}\text { Elodea canadensis } \\
(\mathrm{n}=3)\end{array}$ & $\begin{array}{c}\text { Hydrocharis morsus-ranae } \\
(\mathrm{n}=3)\end{array}$ & $\begin{array}{c}\text { Hydrilla verticillata } \\
(\mathrm{n}=3)\end{array}$ & $\begin{array}{c}\text { Stratiotes aloides } \\
(\mathrm{n}=3)\end{array}$ \\
\hline Валин & $390 \pm 20$ & $420 \pm 30$ & $109 \pm 6$ & $250 \pm 10$ \\
Аргинин & - & - & $250 \pm 10$ & $185 \pm 10$ \\
Триптофан & $250 \pm 10$ & $138 \pm 7$ & - & - \\
Метионин & - & - & $74 \pm 4$ & $94 \pm 6$ \\
Лизин & $80 \pm 5$ & $14 \pm 1$ & $20 \pm 1$ & $15 \pm 1$ \\
Гистидин & $13 \pm 1$ & - & $680 \pm 20$ & $840 \pm 30$ \\
Фенилаланин & - & $240 \pm 10$ & - & - \\
Изолейцин & $720 \pm 10$ & $840 \pm 20$ & & - \\
\hline
\end{tabular}

Примечание: «-»- не обнаружен, ниже предела обнаружения $5 \times 10^{-9}$ г/100 г

Таблица 4. Содержание водорастворимых витаминов в фитомассе растений Hydrocharitaceae

\begin{tabular}{l|c|c|c|c}
\hline \multirow{3}{*}{ Витамин } & \multicolumn{4}{|c}{ Содержание витаминов, 10 } \\
\cline { 2 - 5 } & $\begin{array}{c}\text { Hydrocharis morsus-ranae } \\
(\mathrm{n}=3)\end{array}$ & $\begin{array}{c}\text { Elodea Canadensis } \\
(\mathrm{n}=3)\end{array}$ & $\begin{array}{c}\text { Stratiotes aloides } \\
(\mathrm{n}=3)\end{array}$ & $\begin{array}{c}\text { Hydrilla verticillata } \\
(\mathrm{n}=3)\end{array}$ \\
\hline $\mathrm{B}_{1}$ & $380 \pm 30$ & $280 \pm 20$ & $390 \pm 10$ & $190 \pm 20$ \\
$\mathrm{~B}_{2}$ & $170 \pm 10$ & $120 \pm 10$ & $190 \pm 10$ & $89 \pm 5$ \\
$\mathrm{~B}_{6}$ & $19 \pm 1$ & $17 \pm 1$ & $21 \pm 1$ & $20 \pm 1$ \\
$\mathrm{C}$ & $750 \pm 30$ & $540 \pm 30$ & $770 \pm 30$ & $390 \pm 20$ \\
\hline
\end{tabular}

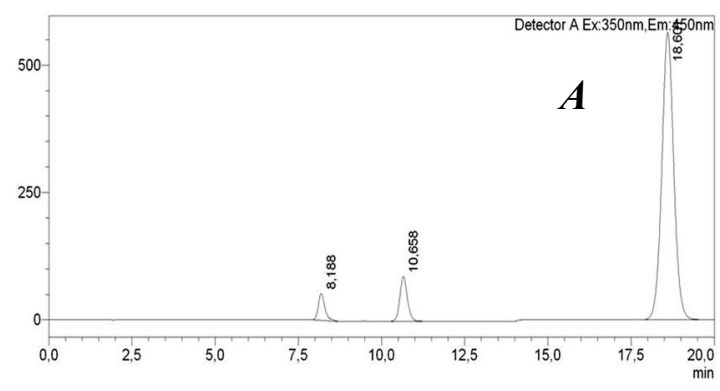

$\mathrm{mV}$

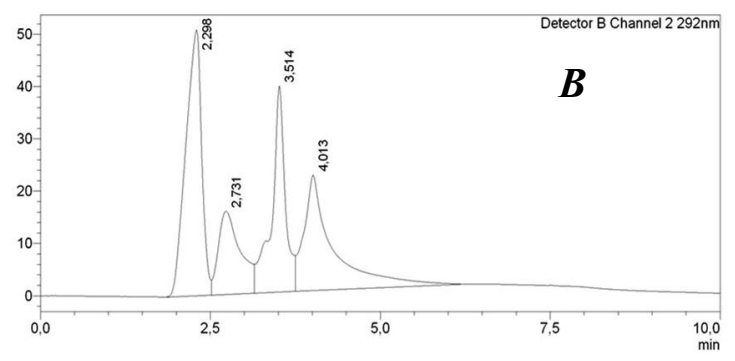

$\mathrm{mV}$
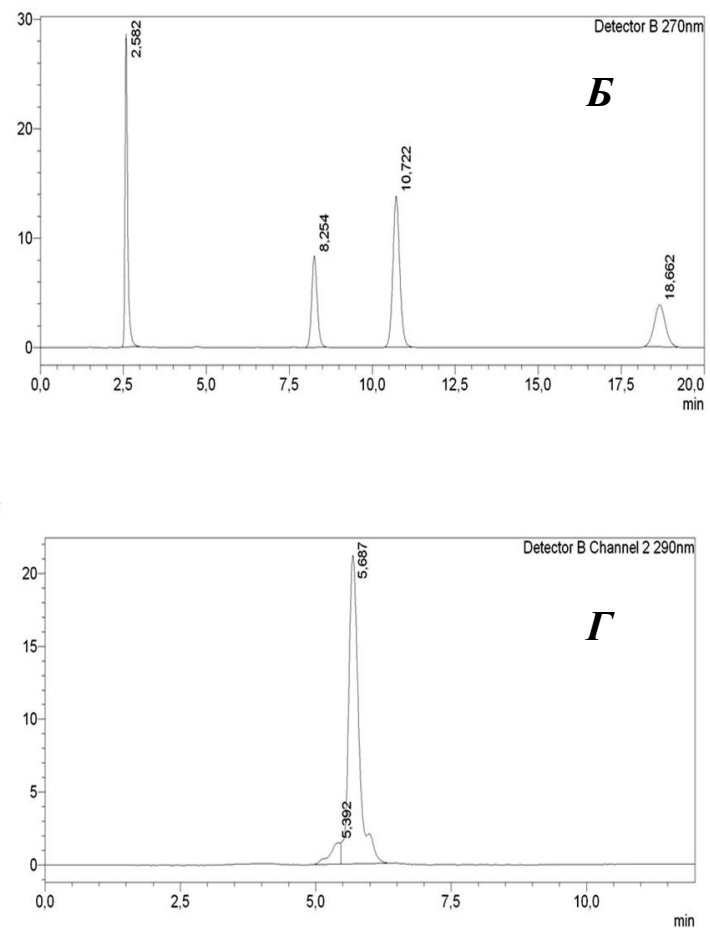

Рис. 1. Хроматограммы определения аминокислот $(A, D)$, витаминов $\mathrm{B}_{1}, \mathrm{~B}_{2}, \mathrm{~B}_{6}(B)$ и витамина $\mathrm{C}(I)$ в фитомассе растений семейства Hydrocharitaceae

Для исследованных растений семейства Hydrocharitaceae свойственно высокое содержание витамина С и низкое $\mathrm{B}_{6}$ (с равными значениям у всех представителей) (табл. 4). В результате кластерного анализа по содержанию водорастворимых витаминов выделяются группы погруженных в воду растений (E. canadensis $+H$. verticillata) и растений, частично экспонирующих ассимиляционную поверхность в воздушную среду (S. aloides $+H$. morsus-ranae) (рис. 2Б). 


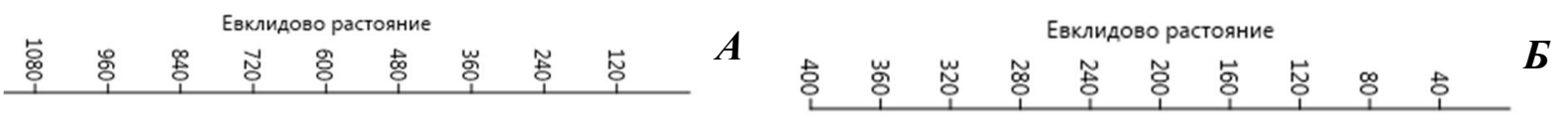
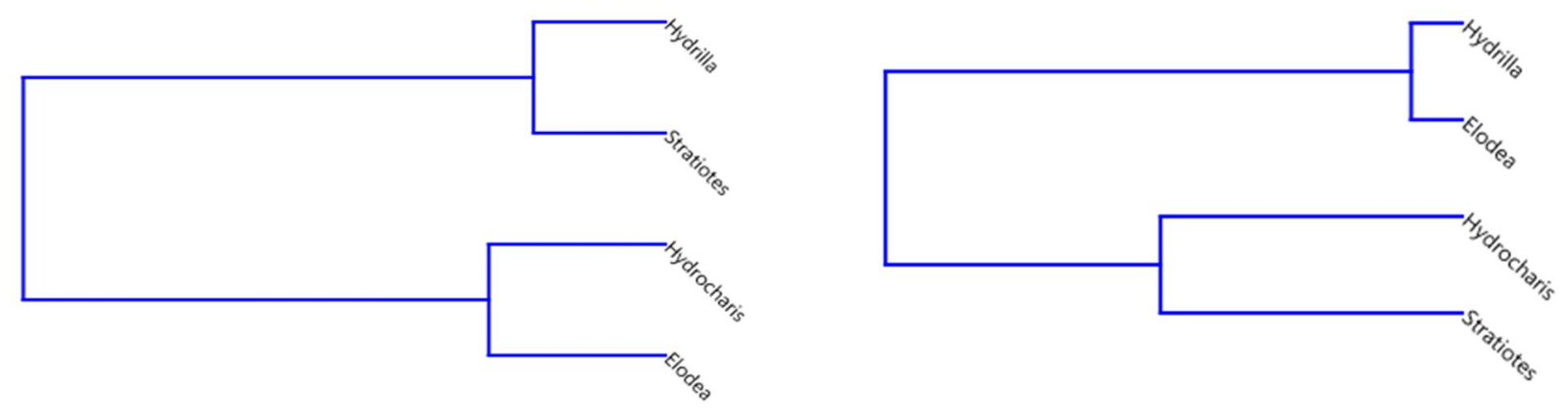

Рис. 2. Сходство исследуемых представителей Hydrocharitaceae по содержанию аминокислот $(A)$, витаминов $(Б)$.

\section{Bblводbl}

У четырех представителей семейства Hydrocharitaceae: E. canadensis, S. aloides, H. morsus-ranae и H. verticillata, произрастающих на территории Западной Сибири, исследовано содержание восьми аминокислот (валина, аргинина, триптофана, метионина, лизина, гистидина, фенилаланина, изолейцина) и четырех водорастворимых витаминов $\left(\mathrm{B}_{1}, \mathrm{~B}_{2}, \mathrm{~B}_{6}\right.$ и $\left.\mathrm{C}\right)$.

У исследуемых растений наблюдается высокое содержание валина, максимальное у H.morsus-ranae $(420 \pm 30) \times 10^{-7}$ г/100 г), метионин не обнаружен. Для представителей семейства характерно сравнительно высокое содержание витамина С (максимальное у S. aloides $(770 \pm 30) \times 10^{-7}$ и H. morsus-ranae $(750 \pm 30) \times$ $10^{-7}$ г/100 г) и низкое $\mathrm{B}_{6}$, у всех исследуемых видов на уровне $(19 \pm 2) \times 10^{-7}$ г/100 г. Это позволяет рассматривать представителей семейства Нydrocharitaceae как потенциальный источник витамина С.

Дальнейшее изучение компонентного состава и поиск биохимических таксонспецифичных признаков могут быть использованы для решения спорных вопросов при установлении внутрисемейственного родства Hydrocharitaceae.

\section{Список литературы}

1. Гребенюк А.В. Семейство Hydrocharitaceae Juss. // Конспект флоры Азиатской России: сосудистые растения. Новосибирск, 2012. С. 431-432.

2. Свириденко Б.Ф. Флора и растительность водоемов Северного Казахстана. Омск, 2000. 196 с.

3. Токарь О.Е. Флора, растительность и фитоиндикация водных экотопов реки Ишим и пойменных озер в пределах Тюменской области. Ишим, 2006. 208 с.

4. Ефремов А.Н., Свириденко Б.Ф. Ресурсы Stratiotes aloides (Hydrocharitaceae) в долинах рек бассейна Среднего Иртыша // Растительные ресурсы. 2012. Т. 8, вып. 2. С. 202-207.

5. Свириденко Б.Ф., Свириденко Т.В., Ефремов А.Н., Токарь О.Е., Евженко К.С. Элодея канадская Elodea canadensis (Hydrocharitaceae) на Западно-Сибирской равнине // Вестник Томского государственного университета. Биология. 2013. №3 (23). С. 46-55.

6. Алехина Е.А., Ефремов А.Н., Егошина А.Е. Фенолгликозиды некоторых представителей семейства водокрасовые (Hydrochariteae) // Фундаментальные и прикладные исследования по приоритетным направлениям биоэкологи и биотехнологии : материалы I Международной научно-практической конференции. Ульяновск, 2014. C. 33-36.

7. Watson L., Dallwitz M.J. Hydrocharitaceae // The families of flowering plants. [Electronic resourse]. URL: http://deltaintkey.com/angio/ www/hydrocha.htm.

8. Johansson J.T. Hydrocharitaceae Juss. // The Phylogeny of Angiosperms. Published online. 2013. URL: http://angio.bergianska.se/monocots/Alismatales/Alismatales.html\#Hydrocharitaceae (01.10.2015).

9. Повыдыш М.В., Петрова Н.В., Бобылева Н.С. Семейство Hydrocharitaceae Juss. - Водокрасовые // Растительные ресурсы России. СПб. ; М., 2014. Т. 6. С. 11-14.

10. Сорокопудова О.А., Дейнека В.И., Сорокопудов В.Н. Хемосистематика: основные положения и особенности // Научные ведомости. 2006. №3 (23). С. 75-83. 
11. Smith P.M. The chemotaxonomy of plants. London: Edward Arnold, 1976. 265 p.

12. Муравьев Д.А. Самылиа И.А., Яковлев Г.В. Фармакогнозия. М., 2007. 656 с.

13. Дубына Д.В., Стойко С.М., Сытник К.М. и др. Макрофиты - индикаторы изменений природной среды. Киев, $1993.434 \mathrm{c}$.

14. Santhanam R., Rajabalaya R., Santhanam R. Freshwater Phytopharmaceutical Compounds. New-York; London, 2013. $250 \mathrm{p}$.

15. Ryan F.J. Nitrogen and carbon concentrations, soluble proteins and free amino acids in subterranean turions of $H y$ drilla during overwintering // Journal Aquatic Plant Manage. 1994. Vol. 32. Pp. 67-70.

16. Ефремов А.Н., Алехина Е.А., Филимонова М.В., Свириденко Б.Ф., Шалыгин С.П., Русак С.Н. Компонентный состав Stratiotes aloides (Hydrocharitaceae) водоемах бассейна Среднего Иртыша // Химия растительного сырья. 2012. №4. С. 161-166.

17. ГОСТ 55482-2013. Мясо и мясные продукты. Метод определения содержания водорастворимых витаминов. M., 2014. 12 c.

18. ГОСТ 13496.21-87 Корма, комбикорма, комбикормовое сырье. Методы определения лизина и триптофана. М., 2011. $12 \mathrm{c}$.

19. ГОСТ 32195-2013 Корма, комбикорма. Метод определения содержания аминокислот. М., 2014. 19 с.

20. Hammer Ø., Harper D.A.T., Ryan P.D. PAST: Paleontological Statistics Software Package for Education and Data Analysis // Palaeontologia Electronica. 2001. N4 (1). 9 p.

Поступило в редакиию 3 декабря 2015 г.

После переработки 29 января 2016 г. 
Efremov A.N. ${ }^{1 *}$, Alehina E.A. ${ }^{1}$, Iminova D.E. ${ }^{2}$, Omargalieva N.K. ${ }^{2}$ ON THE QUESTION OF THE AMINO ACIDS AND WATER-SOLUBLE VITAMINS CONTENT IN SOME SPECIES OF THE FAMILY HYDROCHARITACEAE

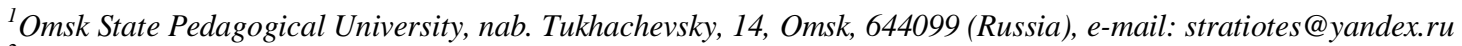

${ }^{2}$ Research Center, State University of radio-ecological Studies named after Shakarim. ul. Fizkulturnaya, 4A, Semey, 071412 (Republic of Kazakhstan)

The research on the amino acids (valine, arginine, tryptophan, methionine, lysine, histidine, phenylalanine, isoleucine) and water-soluble vitamins $\left(\mathrm{B}_{1}, \mathrm{~B}_{2}, \mathrm{~B}_{6}, \mathrm{C}\right)$ content in species of the family Hydrocharitaceae, growing in Western Siberia (Elodea canadensis, Stratiotes aloides Hydrocharis morsus-ranae, Hydrilla verticillata), has been executed.

Five indispensable (valine, isoleucine, lysine, tryptophan, phenylalanine) and two dispensable (arginine, histidine) amino acids have been discovered at examined species of family. It has been found that all examined Hydrocharitaceae have a comparatively high content of valine (H. morsus-ranae has a maximum valine content $\left.\left((420 \pm 30) \times 10^{-7} \mathrm{~g} / 100 \mathrm{~g}\right)\right)$. The high content of vitamin C $\left(\right.$ S. aloides $\left((770 \pm 30) \times 10^{-7}\right)$ and $H$. morsus-ranae $\left((750 \pm 30) \times 10^{-7} \mathrm{~g} / 100 \mathrm{~g}\right)$ have a maximum content $)$ and the equally low content in all examined species of vitamin $\mathrm{B}_{6}$ (at a rate of $\left((19 \pm 2) \times 10^{-7} \mathrm{~g} / 100 \mathrm{~g}\right)$ are typical.

Keywords: Hydrocharitaceae, Stratiotes aloides, Elodea canadensis, Hydrocharis morsus-ranae, Hydrilla verticillata, amino acids, water-soluble vitamins, Western Siberia.

\section{References}

1. Grebenyuk A.V. Konspekt flory Aziatskoj Rossii: sosudistye rasteniya, Novosibirsk, 2012, pp. 431-432. (in Russ.).

2. Sviridenko B.F. Flora i rastitel'nost' vodoemov Severnogo Kazahstana. [Flora and vegetation of water bodies in Northern Kazakhstan]. Omsk, 2000, 196 p. (in Russ.).

3. Tokar' O. E. Flora, rastitel'nost' i fitoindikaciya vodnyh ehkotopov reki Ishim i pojmennyh ozer v predelah Tyumenskoj oblasti. [Flora, vegetation and aquatic habitat bioindication Ishim River and floodplain lakes within the Chu-Tyumen region]. Ishim, 2006, 208 p. (in Russ.).

4. Efremov A.N., Sviridenko B.F. Rastitel'nye resursy, 2012, vol. 8, no. 2, pp. 202-207. (in Russ.).

5. Sviridenko B.F., Sviridenko T.V., Efremov A.N., Tokar' O.E., Evzhenko K.S. Vestnik Tomskogo gosudarstvennogo universiteta. Biologija, 2013, no. 3 (23), pp. 46-55. (in Russ.).

6. Alehina E.A., Efremov A.N., Egoshina A.E. Fundamental'nye $i$ prikladnye issledovanija po prioritetnym napravlenijam bio-jekologi i biotehnologii: materialy I Mezhdunarodnoj nauchno-prakticheskoj konferencii. [Basic and applied research in priority areas of biotechnology and bio-ecology: Proceedings of the I International Scientific and Practical Conference]. Ul'janovsk, 2014, pp. 33-36. (in Russ.).

7. Watson L., Dallwitz M.J. The families of flowering plants. [Electronic resourse]. URL: http://deltaintkey.com/angio/www/hydrocha.htm.

8. Johansson J.T. The Phylogeny of Angiosperms. Published online, 2013, URL: http://angio.bergianska.se/monocots/Alismatales/Alismatales.html\#Hydrocharitaceae.

9. Povydysh M.V., Petrova N.V., Bobyleva N.S. Rastitel'-nye resursy Rossii, 2014, vol. 6, pp. 11-14. (in Russ.).

10. Sorokopudova O.A., Dejneka V.I., Sorokopudov V.N. Nauchnye vedomosti, 2006, no. 3 (23), pp. 75-83. (in Russ.).

11. Smith P.M. The chemotaxonomy of plants. London: Edward Arnold, 1976, 265 p.

12. Murav'ev D.A. Samylia I.A., Jakovlev G.V. Farmakognozija. [Pharmacognosy]. Moscow, 2007, 656 p. (in Russ.).

13. Dubyna D.V., Stojko S.M., Sytnik K.M. i dr. Makrofity - indikatory izmenenij prirodnoj sredy. [Macrophytes indicators of environmental changes]. Kiev, 1993, 434 p. (in Russ.).

14. Santhanam R., Rajabalaya R., Santhanam R. Freshwater Phytopharmaceutical Compounds. New-York; London: CRC Press, 2013, 250 p.

15. Ryan F.J. Journal Aquatic Plant Manage. 1994, vol. 32, pp. 67-70.

16. Efremov A.N., Alehina E.A., Filimonova M.V., Sviridenko B.F., Shalygin S.P., Rusak S.N. Himija rastitel'nogo syr'ja, 2012, no. 4, pp. 161-166. (in Russ.).

17. GOST 55482-2013. Mjaso i mjasnye produkty. Metod opredelenija soderzhanija vodorastvorimyh vitaminov. [GOST 55482-2013. Meat and meat products. Method for determination of water-soluble vitamins]. Moscow, 2014, 12 p. (in Russ.).

18. GOST 13496.21-87 Korma, kombikorma, kombikormovoe syr'e. Metody opredelenija lizina i triptofana. [GOST 13496.21-87 Fodder, mixed fodder, feed raw materials. Methods for the determination of lysine and tryptophan] Moscow, 2011, 12 p. (in Russ.).

19. GOST 32195-2013 Korma, kombikorma. Metod opredelenija soderzhanija aminokislot. [GOST 32195-2013 Forage, feed. Method determination of amino acids]. Moscow, 2014, 19 p. (in Russ.).

20. Hammer Ø., Harper D.A.T., Ryan P.D. Palaeontologia Electronica, 2001, no. 4 (1), 9 p.

Received December 3, 2015

Revised January 29, 2016

\footnotetext{
* Corresponding author.
} 
